Maffulli N, Caine DJ (eds): Epidemiology of Pediatric Sports Injuries: Team Sports.

Med Sport Sci. Basel, Karger, 2005, vol 49, pp 140-169

\title{
Soccer Injuries
}

\author{
Eric Giza ${ }^{\mathrm{a}}$, Lyle J. Micheli ${ }^{\mathrm{b}}$ \\ ${ }^{a}$ Harvard Combined Orthopaedic Surgery Program, Boston, Mass., and \\ ${ }^{b}$ Division of Sports Medicine, Children's Hospital, Boston, Mass., USA
}

\begin{abstract}
Objective: This chapter reviews the existing epidemiological studies on pediatric soccer injuries and discusses possibilities for future research. Data Sources: A comprehensive, web-based search of existing soccer injury literature was performed with an emphasis on the pediatric population. The search encompassed all available studies, including European journals and texts, and initial investigations from the 1970s which serve as a basis of comparison to more recent work. Main Results: Youth soccer is a relatively safe sport with an injury incidence ranging from 2.3 per 1,000 practice hours to 14.8 per 1,000 game hours. Similar to adults, youth soccer injuries occur mostly in the lower extremities, specifically the knee and ankle. Contusions are the most common injury, and minor/moderate injuries predominate. Extrinsic risk factors for youth soccer include: dangerous play, play on small fields, and inclusion of youth players on adult teams. The most important intrinsic risk factor is the relation of knee injury and female gender. Conclusions: Adolescent females suffer a disproportionate number of knee and anterior cruciate ligament injuries compared to adolescent males, but recent injury prevention studies yielded encouraging results. Head injuries in youth soccer are low, and rarely, if ever, occur from head to ball contact. Adherence to the rules of the game, proper coaching, and adequate refereeing are important factors in youth soccer injury prevention.
\end{abstract}

Copyright (C) 2005 S. Karger AG, Basel

\section{Introduction}

Soccer is the world's most popular organized sport with over 200 million males and 21 million females registered with the Fèdèration Internationale de Football Association (FIFA). There has been a considerable increase in soccer participation by American youth over the past two decades. In 1999, the Soccer Industry Council of America estimated that 18.2 million Americans played organized soccer, with 13.8 million players less than 18 years of age. Among 
players aged 12-17, participation in soccer rose $20 \%$ between 1987 and 1999, and high school participation increased 65\% [1-3]. In a comparison of sport participation data from 1983 to 1998 , a $159 \%$ increase in soccer injuries was evident, indicating a large increase in participation for both boys and girls [4].

Investigations in adult male soccer players identified an incidence of 10-35 injuries per 1,000 game hours [5, 6], and adult female studies revealed an incidence of 2-24 injuries per 1,000 player hours [7-10]. Effectively every player incurs one performance limiting injury per year. However, in a review of 20 epidemiological studies on adult soccer injuries, Dvorak and Junge [5] agreed with Inklaar's [11] conclusion that epidemiological information regarding soccer injuries is inconsistent and far from complete.

FIFA estimates that the average world-wide medical cost of a soccer injury is USD 150, leading to an estimated annual cost of USD 30 billion [5]. In professional English soccer, the average cost due to injury is approximately USD 70 million per season [12]. The rise in youth soccer participation, and the subsequent cost associated with injuries, place an enormous economic pressure on the health care system. The new-found popularity of youth soccer challenges sports medicine professionals to not only identify the injury patterns, but also develop effective treatment and prevention programs. The purpose of this chapter is to review the existing studies on pediatric soccer injuries and discuss possibilities for future research.

A comprehensive, web-based search of the existing soccer injury literature was performed with an emphasis on the pediatric population. The search encompassed all available studies, including some initial investigations from the 1970s which serve as a basis of comparison to more recent work. Some studies which included both adult and pediatric subjects were included due to the paucity of pediatric soccer literature and to provide comparison of the two populations. Case series and case reports were included only if the available literature was sparse, and were not used to discuss injury incidence or risk of injury. Soccer is an international sport, and, although all available English (or English translated) papers were reviewed, the chapter may be limited by the exclusion of foreign studies that were not available on English-based search engines. The method of investigation, and even the definition of an injury, varied widely in the literature, therefore decreasing the validity of direct comparison of some studies.

\section{Incidence of Injury}

Soccer has a wide variety of participation levels world-wide, from recreational leagues to international competitions. Even among specific age 
groups, the skill level and goal of participation is quite diverse. For example, a high school player in the United States may play on a relatively low skilled team while the same 'youth club' player in England could be part of a development program for a well-funded, internationally prominent soccer club. Moreover, within each club there can be different teams such as first team and reserve team.

\section{Participation Level, Age, and Gender}

Participation level is an important variable in many studies, but the reader should recognize the limitation of varied terminology between different countries and leagues. The studies from which overall injury rates were determined are summarized in table 1 and grouped into: recreational [13, 14], club [10, 15-23], and mixed (pediatric and adult) [24-27] participation. As seen in table 1, most studies reported the incidence as percentage of total injuries or injuries per number of player hours. Age range is an important factor because many clubs use age to separate teams (10-12-year-old, 14-16-year-old, etc.). In a follow-up study over one season, Schmidt-Olsen found that injury incidence increased with age and older youth players approached the incidence rate in adults $(12-13$ year olds $=3.4 / 1,000 \mathrm{~h}, 14-15$ year olds $=3.8 / 1,000 \mathrm{~h}, 16-17$ year olds $=4.0 / 1,000 \mathrm{~h}$ ) [18]. Inklaar et al. [26] also found that, among highly skilled players, the injury rate in 17-18 year olds was higher than in other youth groups. In 2001, Soderman found that 15-17-year-old girls had a higher injury rate than other age groups [10], supporting Maehlum and Daljord's [24] findings in 1984 that most injuries occurred in the female 15-19-year-old age group.

Inklaar et al. [26] also showed that injury rates increase with age and are higher in the adult population compared to youth players. Nilsson and Roaas's [15] findings show a much higher rate for both girls and boys; however, when minor abrasions and blisters were excluded, the injury incidence was similar to other studies (boys $=14.0 / 1,000 \mathrm{~h}$ and girls $=32.0 / 1,000 \mathrm{~h}$ ). Both Neilsen and Inklaar found that injury incidence, pattern of injury, and traumatology varied between players at different levels of competition, and that injury rates were higher in more competitive players [25, 26]. In contrast, Peterson et al. [27] colleagues performed a prospective, cohort study that compared soccer injuries at different ages and skill levels. They found that low-level youth players had twice as many injuries as high-level youth players in relation to exposure time.

Although soccer epidemiology studies in the 1970s and early 1980s [15, 19] showed that females had a higher injury rate, age and skill level may have more of an influence on injury incidence than gender alone. In a 5-day invitational tournament in 1985 with over 6,000 players, females aged 17-19 showed a much higher injury rate $(47.1 / 1,000 \mathrm{~h})$ compared to males in the same age group (20.6/1,000 h) [17]. In 1984, Maehlum and Daljord [24] studied injuries at the Norway Cup, one of the world's largest youth club tournaments, and found the 
Table 1. A comparison of injury rates in youth soccer

\begin{tabular}{|c|c|c|c|c|c|c|c|c|c|c|}
\hline Study, year & $\begin{array}{l}\text { Age } \\
\text { range } \\
\text { (in } \\
\text { years) }\end{array}$ & $\begin{array}{l}\text { Design } \\
\mathrm{P} / \mathrm{R}\end{array}$ & $\begin{array}{l}\text { Data } \\
\text { collection } \\
\mathrm{I} / \mathrm{Q}\end{array}$ & Duration & $\begin{array}{l}\text { Number of } \\
\text { injuries }\end{array}$ & $\begin{array}{l}\text { Sample number } \\
\text { (number of } \\
\text { players unless } \\
\text { indicated) }\end{array}$ & $\begin{array}{l}\text { Overall } \\
\text { injury rate } \\
\text { per } 1,000 \\
\text { hours }\end{array}$ & $\begin{array}{l}\text { Game injury } \\
\text { rate per } \\
1,000 \text { hours }\end{array}$ & $\begin{array}{l}\text { Practice injury } \\
\text { rate per } \\
1,000 \text { hours }\end{array}$ & $\begin{array}{l}\text { Injury rate, } \\
\text { other }\end{array}$ \\
\hline $\begin{array}{l}\text { Recreational } \\
\text { McCarroll [13], } \\
1984\end{array}$ & $8-18$ & $\mathrm{P}$ & Q & 1 season & 176 & 4,018 & & & & $4.38 \%$ \\
\hline Backous, 1988 & $6-17$ & $\mathrm{P}$ & I & 5 week camp & 216 & 1,139 & 8.95 & & & \\
\hline $\begin{array}{l}\text { Club } \\
\text { Nilsson [15], } \\
1978\end{array}$ & $11-18$ & $\mathrm{P}$ & I & $\begin{array}{l}5 \text { day tour- } \\
\text { nament } \times \\
2 \text { years } \\
(10 \text { days })\end{array}$ & 1,534 & 25,000 & $\begin{array}{l}\text { Boys }=23.0 \\
\text { Girls }=44.0\end{array}$ & & & \\
\hline $\begin{array}{l}\text { Sullivan [16], } \\
1980\end{array}$ & $7-18$ & $\mathrm{P}$ & Q & 1 season & 34 & 1,272 & $\begin{array}{l}\text { Boys }=0.51 \\
\text { Girls }=1.1\end{array}$ & & & 2.6 per 100 players \\
\hline $\begin{array}{l}\text { Schmidt-Olsen } \\
\text { [17], } 1985\end{array}$ & 9-19 & $\mathrm{P}$ & I & $\begin{array}{l}5 \text { day tour- } \\
\text { nament }\end{array}$ & 346 & 6,600 & $\begin{array}{l}\text { All }=19.1 ; \\
\text { Boys }=16.1 \\
\text { Girls }=29.9\end{array}$ & & & \\
\hline $\begin{array}{c}\text { Schmidt-Olsen } \\
{[18], 1991}\end{array}$ & $12-18$ & $\mathrm{P}$ & Q & 1 season & 312 & 496 & 3.7 & & & \\
\hline $\begin{array}{l}\text { Maehlum [19], } \\
1986\end{array}$ & $11-18$ & $\mathrm{P}$ & I & $\begin{array}{l}6 \text { day tour- } \\
\text { nament }\end{array}$ & 411 & 1,348 teams & $\begin{array}{l}\text { All }=11.7 \\
\text { Boys }=9.9 \\
\text { Girls }=17.6\end{array}$ & & & \\
\hline $\begin{array}{l}\text { Maehlum [20], } \\
1999\end{array}$ & $9-19$ & $\mathrm{P}$ & I & $\begin{array}{l}6 \text { day tour- } \\
\text { nament } \times \\
2 \text { years } \\
(12 \text { days })\end{array}$ & $\begin{array}{l}278 \text { (in } \\
1993 \text { ), } \\
296 \text { (in } \\
1997 \text { ) }\end{array}$ & & $\begin{array}{l}7.7 \text { (in 1993), } \\
7.3 \text { (in 1997) }\end{array}$ & & & $\begin{array}{l}\text { Boys = } 7.6 \text { (in 1993), } \\
6.9 \text { (in 1997); } \\
\text { Girls = 8.1 (in 1993), } \\
8.3 \text { (in 1997) }\end{array}$ \\
\hline $\begin{array}{l}\text { Kibler [21], } \\
1993\end{array}$ & $12-19$ & $\mathrm{P}$ & I & $\begin{array}{l}3 \text { day tour- } \\
\text { nament } \times \\
4 \text { years } \\
(12 \text { days })\end{array}$ & 179 & 480 games & 2.38 & & & \\
\hline
\end{tabular}


Table 1 (continued)

\begin{tabular}{|c|c|c|c|c|c|c|c|c|c|c|}
\hline Study, year & $\begin{array}{l}\text { Age } \\
\text { range } \\
\text { (in } \\
\text { years) }\end{array}$ & $\begin{array}{l}\text { Design } \\
\mathrm{P} / \mathrm{R}\end{array}$ & $\begin{array}{l}\text { Data } \\
\text { collection } \\
\mathrm{I} / \mathrm{Q}\end{array}$ & Duration & $\begin{array}{l}\text { Number of } \\
\text { injuries }\end{array}$ & $\begin{array}{l}\text { Sample number } \\
\text { (number of } \\
\text { players unless } \\
\text { indicated) }\end{array}$ & $\begin{array}{l}\text { Overall } \\
\text { injury rate } \\
\text { per } 1,000 \\
\text { hours }\end{array}$ & $\begin{array}{l}\text { Game injury } \\
\text { rate per } \\
1,000 \text { hours }\end{array}$ & $\begin{array}{l}\text { Practice injury } \\
\text { rate per } \\
1,000 \text { hours }\end{array}$ & $\begin{array}{l}\text { Injury rate, } \\
\text { other }\end{array}$ \\
\hline $\begin{array}{l}\text { Junge [22], } \\
2000^{*}\end{array}$ & $14-18$ & $\mathrm{P}$ & I & 1 year & $\begin{array}{l}\text { France }=58 \\
\text { Czech }=130\end{array}$ & $\begin{array}{l}\text { France }=131 \\
\text { Czech }=180\end{array}$ & & $\begin{array}{l}\text { France }=12.7 \\
\text { Czech }=14.8\end{array}$ & $\begin{array}{l}\text { France }=2.3 \\
\text { Czech }=2.6\end{array}$ & \\
\hline $\begin{array}{c}\text { Elias [23] } \\
2001^{* *}\end{array}$ & $9-19$ & $\mathrm{P}$ & I & $\begin{array}{l}6 \text { day tour- } \\
\text { nament } \times \\
10 \text { years } \\
(60 \text { days })\end{array}$ & 3,840 & 89,500 & & & & $\begin{array}{l}\text { Boys }=7.60(\min )- \\
20.04(\max ) \\
\text { Girls }=10.23(\min )- \\
20.11(\max )\end{array}$ \\
\hline Soderman, 2001 & $14-19$ & $\mathrm{P}$ & I and Q & 1 season & 79 (Girls only) & 175 & 6.8 & 9.1 & 1.5 & \\
\hline \multicolumn{11}{|l|}{$\begin{array}{l}\text { Multiple Age } \\
\text { Group }\end{array}$} \\
\hline $\begin{array}{l}\text { Maehlum [24], } \\
1984\end{array}$ & $5-60$ & $\mathrm{R}$ & I & 1 year & 1,329 & & & $\begin{array}{l}\text { Male }=3.3 \\
(\text { all ages }) \\
\text { Female }=4.9 \\
(\text { all ages })\end{array}$ & & \\
\hline $\begin{array}{l}\text { Nielsen [25], } \\
1989\end{array}$ & $\begin{array}{l}16- \\
\text { adult }\end{array}$ & $\mathrm{P}$ & I & 1 season & $\begin{array}{l}\text { All ages = 109; } \\
\text { Youth }=27\end{array}$ & $\begin{array}{l}\text { Adult }=93 \\
\text { Youth }=30\end{array}$ & & $\begin{array}{l}\text { High level } \\
\text { adult }=18.5 ; \\
\text { Youth }=14.4\end{array}$ & $\begin{array}{l}\text { High level } \\
\text { adult }=2.3 ; \\
\text { Youth }=3.6\end{array}$ & \\
\hline $\begin{array}{l}\text { Inklaar [26], } \\
1996\end{array}$ & $13-60$ & $\mathrm{P}$ & Q & 1 season & 83 & $\begin{array}{l}\text { Adult }=245 \\
\text { Youth }=232\end{array}$ & $\begin{array}{l}13-14 \text { years }= \\
12.8 ; \\
15-16 \text { years }= \\
16.1 ; \\
17-18 \text { years }= \\
28.3\end{array}$ & & & $\begin{array}{l}17-18 \text { years and high } \\
\text { skill = 34.6; } \\
17-18 \text { years and low } \\
\text { skill }=15.7\end{array}$ \\
\hline $\begin{array}{l}\text { Peterson [27], } \\
2000\end{array}$ & $\begin{array}{l}14- \\
\text { adult }\end{array}$ & $\mathrm{P}$ & I & 1 year & 558 & 264 & $\begin{array}{l}16-18 \text { years and } \\
\text { high skill }=6.6 ; \\
16-18 \text { years and } \\
\text { low skill }=13.7\end{array}$ & & & $\begin{array}{l}\text { Adult } \\
\text { professional }=5.6 \text {; } \\
\text { Adult amateur }=4.6 \text {; } \\
\text { Adult club }=20.2\end{array}$ \\
\hline
\end{tabular}

*Study compared youth injuries in France to the Czech Republic (Czech); see text for details.

**Injury rates varied over the 10 years of the tournament maximum (max) and minimum (min) values are show for each gender.
} 
injury rate to be twice as high in girls as boys. In 1999, Maehlum et al. [20] again compared values from the 1984 tournament to the 1993 and 1997 tournaments, and found a $35 \%$ total decrease in total injuries with a $50 \%$ reduction in female injuries [20]. Elias also found a decline in injury rates for both girls and boys during a large American tournament over a 10-year period [23]. While some studies have shown that youth soccer injury rates are higher in highskilled players [26], others have shown that low-skilled players are more at risk for injury [27]. High-skilled players train more often and presumably compete more intensely, but poor conditioning and fitness in low-skilled players may lead to more injuries. Comparison of the data in table 1 has shown a narrowing of the injury rate between girls and boys over time, and, if it is presumed that the early injury rates in females are secondary to low skill levels, then the increase in soccer skills and training in girls from the 1980s to 1990s may indicate a relationship between decreased injury and improved soccer skills. Indeed, a study by the FIFA Medical Assessment and Research Centre (FIFAMARC) in 2002 showed that improved training in low-skilled soccer players can lead to a reduction in injury rates [28].

\section{Player Position}

A comparison of injury rates and player position is shown in table 2 [16, 29-31]. Only one study has directly compared injury rates and player position [30]. Accounting for the fact that there are only one or two goalkeepers per team, Junge et al. [30] found that goalkeepers have similar physical and psychological profiles to field players, but a $25 \%$ lower injury incidence. There is a specific relationship between injury and player position (table 2), except for Boden's [31] retrospective review of tibia/fibula fractures, who found that forwards suffered nearly $40 \%$ of these severe injuries.

\section{Injury Characteristics}

\section{Injury Onset}

The majority of injuries in youth soccer occur acutely. In a study of adolescent female soccer players, $34 \%$ of injuries were chronic [10]. The FIFAMARC studies of youth soccer injuries revealed that overuse injuries accounted for approximately $18 \%$ of injuries and that the number of chronic injuries decreased with a preseason conditioning program $[22,28]$.

\section{Injury Location}

A comparison of anatomical injury location in youth soccer studies is shown in table 3. [10, 13, 15-19, 21-23, 25, 26, 32]. Table 3 shows that the 
Table 2. A comparison of injury rates and player position in youth soccer

\begin{tabular}{|c|c|c|c|c|c|c|c|c|c|c|}
\hline Study & $\begin{array}{l}\text { Age range } \\
\text { (in years) }\end{array}$ & $\begin{array}{l}\text { Design } \\
\mathrm{P} / \mathrm{R}\end{array}$ & $\begin{array}{l}\text { Data } \\
\text { collection } \\
\text { I/Q }\end{array}$ & $\begin{array}{l}\text { Number } \\
\text { of } \\
\text { injuries }\end{array}$ & $\begin{array}{l}\text { Sample number } \\
\text { (number of } \\
\text { players unless } \\
\text { indicated) }\end{array}$ & $\begin{array}{l}\text { Goalkeeper } \\
(\mathrm{n}=\text { number of } \\
\text { players unless } \\
\text { indicated) }\end{array}$ & Defender & Midfield & Forward & $\begin{array}{l}\text { Unknown } \\
\text { position at } \\
\text { time of } \\
\text { injury }\end{array}$ \\
\hline $\begin{array}{l}\text { Sullivan [16] } \\
1980\end{array}$ & $7-18$ & $P$ & Q & 34 & 1,272 & $6,17.6 \%$ & $11,32.4 \%$ & $6,17.6 \%$ & $11,32.4 \%$ & \\
\hline $\begin{array}{l}\text { Powell [29], } \\
1999 \text { (Only } \\
\text { head injuries) }\end{array}$ & & $\mathrm{P}$ & I & $\begin{array}{l}\text { Boys }=69 \\
\text { Girls }=76\end{array}$ & 246 teams & $\begin{array}{l}\text { Boys }=11.9 \% \\
\text { Girls }=18.8 \%\end{array}$ & & $\begin{array}{l}\text { Boys } \\
\text { (forwards and } \\
\text { midfield) }= \\
66.1 \%\end{array}$ & $\begin{array}{l}\text { Girls } \\
\text { (forwards and } \\
\text { midfield) }= \\
70.3 \%\end{array}$ & \\
\hline $\begin{array}{l}\text { Boden [31], } \\
1998 \text { (Only } \\
\text { tibia/fibula } \\
\text { fractures) }\end{array}$ & 19 & $\mathrm{R}$ & Q & 31 & 31 & $2,6 \%$ & $6,19 \%$ & $5,19 \%$ & $13,42 \%$ & $5,16 \%$ \\
\hline $\begin{array}{l}\text { Junge [30], } \\
2001\end{array}$ & $\begin{array}{c}\text { 14-18 years, } \\
\text { and adults }\end{array}$ & $\mathrm{P}$ & I and Q & $\begin{array}{l}\mathrm{GK}=47 \\
\mathrm{~F}=511\end{array}$ & $\begin{array}{l}\text { GK }(\text { all })=28 \\
\text { Field }(\text { all })=236 \\
\text { GK }(<18 \text { yrs })=20 \\
\text { Field }(<18 \text { yrs })= \\
179\end{array}$ & $\begin{array}{l}\text { All }=6.09 ; \\
16-18 \text { and high } \\
\text { level = 4.68; } \\
16-18 \text { and low } \\
\text { level = } 7.46 ; \\
14-16 \text { and high } \\
\text { level = 3.08; } \\
14-16 \text { and low } \\
\text { level }=8.83\end{array}$ & $\begin{array}{l}\text { Field }(\text { all })= \\
7.42\end{array}$ & & & \\
\hline
\end{tabular}


Table 3. A comparison of anatomical injury location in youth soccer. All studies are prospective and players are youth club unless indicated. $\mathrm{N}=$ player sample, percentage, unless indicated

\begin{tabular}{|c|c|c|c|c|c|c|c|c|c|c|c|c|c|c|}
\hline & $\begin{array}{l}\text { Author } \\
\text { Year }\end{array}$ & $\begin{array}{l}\text { Nilsson } \\
{[15]} \\
1978\end{array}$ & $\begin{array}{l}\text { Sullivan } \\
{[16]} \\
1980\end{array}$ & $\begin{array}{l}\text { Schmidt- } \\
\text { Olsen [17] } \\
1985\end{array}$ & $\begin{array}{l}\text { Maehlum } \\
{[19]} \\
1986\end{array}$ & $\begin{array}{l}\text { Hoff* } \\
{[32]} \\
1986\end{array}$ & $\begin{array}{l}\text { Backous } \\
{[13]} \\
1988\end{array}$ & $\begin{array}{l}\text { Nielsen } \\
{[25]} \\
1989\end{array}$ & $\begin{array}{l}\text { Schmidt- } \\
\text { Olsen [18] } \\
1991\end{array}$ & $\begin{array}{l}\text { Kibler } \\
{[21]} \\
1993\end{array}$ & $\begin{array}{l}\text { Inklaar } \\
{[26]} \\
1996\end{array}$ & $\begin{array}{l}\text { Junge** } \\
{[22]} \\
2000\end{array}$ & $\begin{array}{l}\text { Elias*** } \\
{[23]} \\
2001\end{array}$ & $\begin{array}{l}\text { Soderman } \\
2001\end{array}$ \\
\hline $\begin{array}{l}\text { Injury } \\
\text { site }\end{array}$ & $\begin{array}{l}\text { Sample } \\
\text { number }\end{array}$ & 25,000 & 1,272 & 6,600 & $\begin{array}{l}1,348 \\
\text { teams }\end{array}$ & 821 & 1,139 & 30 & 496 & & 232 & 311 & 89,500 & 175 \\
\hline Head & & $\begin{array}{l}54, \\
10 \%\end{array}$ & 5 & $\begin{array}{l}17, \\
4.9 \%\end{array}$ & $71,17.3 \%$ & $\begin{array}{c}\mathrm{O}=10 \\
22 \% \\
\mathrm{I}=6,8 \%\end{array}$ & 7 & & $1.2 \%$ & $8 \%$ & & & $\begin{array}{c}\mathrm{M}=288 \\
1.56 \\
\mathrm{~F}=187 \\
1.76\end{array}$ & \\
\hline Face & & & & & & & 8 & & $1.9 \%$ & & & & & \\
\hline Trunk & & $37,7 \%$ & 1 & $7,2.0 \%$ & $31,7.5 \%$ & $\begin{array}{c}\mathrm{O}=4 \\
8 \% \\
\mathrm{I}=11 \\
15 \%\end{array}$ & & & & & & & & \\
\hline Back & & & & $6,1.8 \%$ & & & 6 & & $13.8 \%$ & & & & & $1,1.9 \%$ \\
\hline Abdomen & & & & & & & & & & $10.9 \%$ & & & & \\
\hline $\begin{array}{l}\text { Upper } \\
\text { extremity }\end{array}$ & & $\begin{array}{l}80 \\
15 \%\end{array}$ & 6 & & $58,14.1 \%$ & $\begin{array}{l}\mathrm{O}=3,6 \% \\
\mathrm{I}=14 \\
20 \%\end{array}$ & & & & & & & $\begin{array}{c}\mathrm{M}=278 \\
1.51 \\
\mathrm{~F}=154 \\
1.45\end{array}$ & $2,3.9 \%$ \\
\hline Shoulder & & & & $6,1.8 \%$ & & & & & $2.6 \%$ & & & & & \\
\hline Arm & & & & $8,2.3 \%$ & & & & & $7.7 \%$ & & & & & \\
\hline Wrist & & & & & & & 4 & & & & & & & \\
\hline Hand & & & & $22,6.3 \%$ & & & 6 & & & & & & & \\
\hline $\begin{array}{l}\text { Lower } \\
\text { extremity }\end{array}$ & & & & & $\begin{array}{l}251 \\
\quad 61.0 \%\end{array}$ & $\begin{array}{c}\mathrm{O}=26 \\
63 \% \\
\mathrm{I}=43 \\
58 \%\end{array}$ & & & & & & & $\begin{array}{c}\mathrm{M}=1435 \\
7.79 \\
\mathrm{~F}=860 \\
8.09\end{array}$ & \\
\hline
\end{tabular}


Table 3 (continued)

\begin{tabular}{|c|c|c|c|c|c|c|c|c|c|c|c|c|c|c|}
\hline & Author & $\begin{array}{l}\text { Nilsson } \\
{[15]} \\
1978\end{array}$ & $\begin{array}{l}\text { Sullivan } \\
{[16]} \\
1980\end{array}$ & $\begin{array}{l}\text { Schmidt- } \\
\text { Olsen [17] } \\
\text { 1985 }\end{array}$ & $\begin{array}{l}\text { Maehlum } \\
{[19]} \\
1986\end{array}$ & $\begin{array}{l}\text { Hoff* } \\
{[32]} \\
11966\end{array}$ & $\begin{array}{l}\text { Backous } \\
{[13]}\end{array}$ & $\begin{array}{l}\text { Nielsen } \\
{[25]} \\
1989\end{array}$ & $\begin{array}{l}\text { Schmidt- } \\
\text { Olsen [18] }\end{array}$ & $\begin{array}{l}\text { Kibler } \\
{[21]} \\
1993\end{array}$ & $\begin{array}{l}\text { Inklaar } \\
{[26]} \\
1996\end{array}$ & $\begin{array}{l}\text { Junge** } \\
{[22]} \\
2000\end{array}$ & $\begin{array}{l}\text { Elias*** } \\
{[23]} \\
2001\end{array}$ & $\begin{array}{l}\text { Soderman } \\
2001\end{array}$ \\
\hline & & & & & & & & & & & & & & \\
\hline $\begin{array}{r}\text { Pelvis/ } \\
\text { Groin }\end{array}$ & & & & $7,2.0 \%$ & & & 6 & $\begin{array}{l}4, \\
14.8 \%\end{array}$ & $7.1 \%$ & & & $\begin{array}{c}\mathrm{F}=3 \\
5.3 \% \\
\mathrm{Cz}=10 \\
7.7 \%\end{array}$ & & $1,1.9 \%$ \\
\hline Hip & & & & & & & & & $1.8 \%$ & & & & & \\
\hline Thigh & & $16,12 \%$ & & $\begin{array}{l}51 \\
14.8 \%\end{array}$ & & & 18 & & & $21 \%$ & 11 & $\begin{array}{c}\mathrm{F}=8 \\
14.0 \% \\
\mathrm{Cz}=22 \\
16.9 \%\end{array}$ & $\begin{array}{c}\mathrm{M}=323 \\
1.65 \\
\mathrm{~F}=106 \\
1.00\end{array}$ & $14,26.9 \%$ \\
\hline Knee & & $72,14 \%$ & 4 & $\begin{array}{l}35, \\
10.1 \%\end{array}$ & & & 27 & $\begin{array}{l}6 \\
22.2 \%\end{array}$ & $26 \%$ & $15.8 \%$ & 11 & $\begin{array}{c}\mathrm{F}=14 \\
24.6 \% \\
\mathrm{Cz}=27 \\
20.8 \%\end{array}$ & $\begin{array}{c}\mathrm{M}=348 \\
1.89 \\
\mathrm{~F}=271 \\
2.55\end{array}$ & $8,15.4 \%$ \\
\hline Leg & & $67,13 \%$ & & $\begin{array}{l}35 \\
10.1 \%\end{array}$ & & & 34 & & $10.9 \%$ & & 7 & $\begin{array}{c}\mathrm{F}=4 \\
7.0 \% \\
\mathrm{Cz}=7 \\
5.4 \%\end{array}$ & $\begin{array}{c}\mathrm{M}=216 \\
1.56 \\
\mathrm{~F}=104 \\
0.98\end{array}$ & $3,5.8 \%$ \\
\hline Ankle & & $84,16 \%$ & 14 & $\begin{array}{l}55 \\
15.9 \%\end{array}$ & & & 41 & $\begin{array}{l}10 \\
37.0 \%\end{array}$ & $23.1 \%$ & $13 \%$ & 8 & $\begin{array}{c}\mathrm{F}=17 \\
29.8 \% \\
\mathrm{Cz}=27 \\
20.8 \%\end{array}$ & $\begin{array}{c}\mathrm{M}=402 \\
2.18 \\
\mathrm{~F}=308 \\
2.90\end{array}$ & $\begin{array}{l}18, \\
34.6 \%\end{array}$ \\
\hline Foot & & $67,13 \%$ & & $\begin{array}{l}97 \\
28 \%\end{array}$ & & & 22 & $\begin{array}{l}2, \\
7.4 \%\end{array}$ & $0.3 \%$ & $12.8 \%$ & & & $\begin{array}{c}\mathrm{M}=196 \\
1.06 \\
\mathrm{~F}=86 \\
0.81\end{array}$ & $5,9.6 \%$ \\
\hline Other & & & & & & & 37 & $\begin{array}{l}5, \\
18.5 \%\end{array}$ & $2.2 \%$ & & 6 & $\begin{array}{c}\mathrm{F}=11 \\
19.3 \% \\
\mathrm{Cz}=36 \\
7.7 \%\end{array}$ & & \\
\hline
\end{tabular}

*Comparison of outdoor $(\mathrm{O})$ and indoor $(\mathrm{I})$ soccer.

**Comparison of youth soccer injuries in France (F) and Czech Republic (Cz).

${ }^{* * *}$ Comparison of male $(\mathrm{M})$ and female $(\mathrm{F})$ injuries. $\mathrm{N}=$ injuries, injuries $/ 1,000$ player hours. 
lower extremity is involved in approximately $60 \%$ of injuries, and is the most common injury location in youth soccer. The knee and ankle are the most common sites of injury, in agreement with the adult literature [6, 11, 33, 34]. Upper extremity injuries account for up to $20 \%$ of youth injuries, slightly higher than reported for adults $[11,34]$.

\section{Concussion/Head Injury}

Boden et al. [35] determined the incidence of concussion in female collegiate soccer players to be 0.44 per 1,000 athlete exposures; approximately one concussion every 13.5 weeks or one concussion per team per year. The same group also found that $76 \%$ of concussions resulted from player-to-player or player-to-object collision (goal post, elbow, sideline advertisement), and only $24 \%$ resulted from head-to-ball contact from a ball kicked at full force at a close range [35].

\section{Knee Injuries}

The knee can account for up to $25 \%$ of all injuries (table 3), similar to adult soccer populations $[6,7,9,26,33,36-38]$. The high incidence of anterior cruciate ligament (ACL) injuries in young female soccer players is alarming. In adults, ACL injury incidence is 0.10 per 1,000 hours, and other investigators found 0.31 adult ACL injuries per 1,000 hours [9, 39].

More adolescent female than male soccer players required ACL reconstruction over a 6-year period at a pediatric sports specialty center [40]. A 1995 study by Arendt and Dick [41] found that female collegiate soccer and basketball players had a significantly higher ACL injury rate than men (0.31 female vs. 0.16 male per 1,000 athlete exposures) [41]. The 1999-2000 National Collegiate Athletic Association injury surveillance data shows the same pattern in young adults and demonstrates that the injury rate is higher in games than practice $[42,43]$.

\section{Eye Injuries}

In a retrospective review of 15 eye injuries which required ophthalmologic consultation, Orlando [44] found hyphema (bleeding within the anterior eye chamber) to be the most common affliction. Six of the fifteen injuries occurred from an underinflated ball which deformed upon striking the head and entered the orbital area.

\section{Wrist Injuries}

Upper extremity injuries occur at a much lower frequency than lower extremity injuries (table 3). However, Junge et al. [30] have shown that goalkeepers suffer more upper extremity injuries than field players, but less injuries 
overall (table 3). In 2001, Boyd et al. [45] prospectively collected data on 1,920 new fractures seen at a pediatric orthopedic center over one year, 29 of which were wrist fractures in youth goalkeepers. They found that a significant number of wrist fractures in children older than 11 years occurred as a result of impact from adult-sized (size five) balls, and suggested that young players should use appropriately sized balls.

\section{Situational Factors}

Geographical Region

Injury epidemiology can also vary according to country. In 2000, Junge et al. [22] showed that injury incidence did not vary between youth soccer programs in France and the Czech Republic, but that the number of injuries committed secondary to fouls was higher in the Czech Republic. It is therefore important for the team physician, trainer, or coach to recognize that injury patterns can change in different soccer regions or with different styles of play.

Practice versus Game

A FIFA-MARC study reported that half of youth players consider 'fair fouls' a regular part of the game, and that acceptance of intentional rule violations increases with age and experience [46]. As seen in table 1, youth soccer game injury rates are higher than practice rates [10, 25, 42, 43, 47]. The injury rates reported in tournament-related studies are similar to those for game rates, as tournaments consist primarily of games [15, 17, 19, 23]. Game injury rates are much higher in adults, probably because players will compete more intensely during a match $[6,11,33,36]$.

\section{Indoor versus Outdoor}

A comparison of studies with injury data on indoor and outdoor soccer is shown in table $4[32,48]$. The incidence of indoor soccer injuries in adults has been reported as 4.4 per 100 player hours [49], which is similar to outdoor rates for adults $[11,50]$. Indoor soccer has a higher incidence than outdoor soccer due to the smaller playing area, use of walls, and artificial surface $[32,48,49]$. However, only one questionnaire-type study directly compared indoor and outdoor soccer in children [32]. In that study, the incidence of injuries is 4.5 times higher for indoor soccer compared to outdoor soccer, injuries increased with increasing age, and children less than 10 years had relatively few injuries for both indoor and outdoor soccer [32]. Lindenfeld et al. [48] prospectively followed a population of children and adults during one indoor soccer season, and found injury rates similar to outdoor soccer (table 4). 
Table 4. A comparison of indoor and outdoor injury rates in youth soccer

\begin{tabular}{|c|c|c|c|c|c|c|c|c|c|c|c|c|}
\hline Study & Year & $\begin{array}{l}\text { Age } \\
\text { range } \\
\text { (in } \\
\text { years) }\end{array}$ & $\begin{array}{l}\text { Design } \\
\mathrm{P} / \mathrm{R}\end{array}$ & $\begin{array}{l}\text { Data } \\
\text { collection } \\
\mathrm{I} / \mathrm{Q}\end{array}$ & Duration & $\begin{array}{l}\text { Number of } \\
\text { injuries }\end{array}$ & $\begin{array}{l}\text { Sample } \\
\text { number } \\
\text { (number of } \\
\text { players } \\
\text { unless } \\
\text { indicated) }\end{array}$ & $\begin{array}{l}\text { Indoor } \\
\text { injury } \\
\text { rate per } \\
100 \text { hours }\end{array}$ & $\begin{array}{l}\text { Outdoor } \\
\text { injury } \\
\text { rate per } \\
100 \text { hours }\end{array}$ & $\begin{array}{l}\text { Practice } \\
\text { injuries } \\
\text { (number of } \\
\text { injuries, } \\
\text { percent) }\end{array}$ & $\begin{array}{l}\text { Game injuries } \\
\text { (number of } \\
\text { injuries, } \\
\text { percent) }\end{array}$ & $\begin{array}{l}\text { Injury } \\
\text { rate, } \\
\text { other }\end{array}$ \\
\hline Hoff [32] & 1986 & $8-15$ & $P$ & Q & 1 season & $\begin{array}{l}\text { Outdoor }= \\
46 ; \\
\text { Indoor }= \\
74\end{array}$ & $\begin{array}{l}\text { Outdoor }= \\
455 ; \\
\text { Indoor }= \\
366\end{array}$ & 10.11 & 5.08 & $\begin{array}{l}\text { Outdoor }=13 \text {, } \\
30.2 \% \text {; } \\
\text { Indoor }=4 \text {, } \\
5.5 \%\end{array}$ & $\begin{array}{l}\text { Outdoor }=33 \text {, } \\
(69.8 \%) \text {; } \\
\text { Indoor }=70 \text {, } \\
(94.5 \%)\end{array}$ & \\
\hline $\begin{array}{l}\text { Lindenfeld } \\
{[48]^{*}}\end{array}$ & 1994 & $7-50$ & $P$ & I & $\begin{array}{l}7 \text { weeks } \\
\text { (adults), } \\
3 \text { weeks } \\
\text { (kids) }\end{array}$ & 136 (all) & 300 games & $\begin{array}{l}\text { All ages }= \\
5.0 \\
<12 \text { yrs: } \\
\mathrm{M}=2.8 \\
\mathrm{~F}=5.6 \\
12-15 \mathrm{yrs} \\
\mathrm{M}=4.4 \\
\mathrm{~F}=6.3 \\
16-18 \mathrm{yrs} \\
\mathrm{M}=4.9 \\
\mathrm{~F}=4.6\end{array}$ & & & & \\
\hline
\end{tabular}


Table 5. A comparison of injury rates and injury mechanism in youth soccer. All studies are prospective unless indicated

\begin{tabular}{|c|c|c|c|}
\hline Study & $\begin{array}{l}\text { Number of } \\
\text { injuries }\end{array}$ & $\begin{array}{l}\text { Number of } \\
\text { injuries with } \\
\text { player contact } \\
\text { (N, \%, unless } \\
\text { indicated) }\end{array}$ & $\begin{array}{l}\text { Number of } \\
\text { injuries without } \\
\text { player contact } \\
(\mathrm{N}, \% \text {, unless } \\
\text { indicated) }\end{array}$ \\
\hline Heidt [53]* & $\begin{array}{l}\text { Trained }=7 ; \\
\text { Control }=91\end{array}$ & $\begin{array}{l}\text { All players }=36,37 \% \\
\text { Trained }=3,42.9 \% \\
\text { Control }=33,36.3 \%\end{array}$ & $\begin{array}{l}\text { All players }=62,63 \% ; \\
\text { Trained }=7,57.1 \% ; \\
\text { Control }=55,63.7 \%\end{array}$ \\
\hline Junge [22]** & $\begin{array}{l}\text { France }=58 \\
\text { Czech }=130\end{array}$ & $\begin{array}{l}\text { France }=28 \\
\text { Czech }=58\end{array}$ & $\begin{array}{l}\text { France }=20 \\
\text { Czech }=70\end{array}$ \\
\hline Junge $[28]^{*}$ & $\begin{array}{l}\text { Trained }=77 ; \\
\text { Control }=111\end{array}$ & $\begin{array}{l}\text { Trained }=0.43 \text { per } \\
\text { player per year; } \\
\text { Control }=0.74 \text { per } \\
\text { player per year }{ }^{¥}\end{array}$ & $\begin{array}{l}\text { Trained }=0.34 \text { per } \\
\text { player per year; } \\
\text { Control }=0.45 \text { per } \\
\text { player per year }\end{array}$ \\
\hline Kibler [21] & 179 & $56.3 \%$ & \\
\hline
\end{tabular}

*Study involved comparison of group with preseason injury prevention program (Trained) and control group (Control).

**Not all injuries had exact injury mechanism.

${ }^{*}$ Statistically significant value $(\mathrm{p}<0.05)$ between two groups.

\section{Action or Activity}

The outcome of certain injuries is related to the injury mechanism. For example, severe adult ankle injuries are more likely to occur from a contact situation where the foot is planted on the ground [51], while Delfico and Garrett [52] showed that $72 \%$ of ACL injuries in soccer occurred from noncontact situations [52]. A comparison of injury mechanisms in youth soccer is shown in table $5[21,22,28,53]$. In the pediatric population, player-to-player contact accounted for approximately half of the injuries [22], and contact occurred in one third of the injuries [53]. Two studies have compared controls to a group of youth players who underwent preseason conditioning [28, 53]. In one study, the control group suffered more injuries due to player-to-player contact, and this could indicate that fitter players are less likely to be hurt during contact situations, such as tackling or heading [28]. In the other investigation, there was no difference in the number of injuries in controls and conditioned players, although this finding may be incidental due to the number of participants [53]. Youth players are most frequently injured during tackles, while professionals are most frequently injured while running. This could indicate that adults or better conditioned adolescents fare better in contact situations [25]. 


\section{Chronometry}

Injury Time During Game/Practice

Drawer and Fuller [12] showed that in professional and World Cup soccer more injuries occur during the second half of a game [6, 33, 37]. In college athletes, a similar game pattern was found, but no relationship to practice time was found $[42,43]$.

Time of Year

There is a correlation between heat illness and summer soccer tournaments: heat illnesses accounted for $4.5 \%$ of injuries in a summer tournament [21]. Elias [23] studied a large summer tournament in Minnesota for over 10 years, and found that the number of heat related illness cases were related to the ambient temperature. Physicians, coaches and trainers should be aware of potential dehydration, and encourage frequent water breaks during summer camps and tournaments $[54,55]$.

\section{Injury Severity}

\section{Injury Type}

A summary of studies reporting injury type data is shown in table 6 . $[10,13-16,18,19,21,23,32,35,44,53,56,57]$ As with adult soccer injury studies $[34,37,50]$, contusions represent the most common injury in youth soccer $(25-47 \%)$. Sprains (20-35\%) and muscular strains (8-25\%) are also common, and fortunately fractures/dislocations are uncommon and represent approximately $3-12 \%$ of injuries reported.

Avulsion Fractures

Rossi and Dragoni [57] reviewed 238 radiographs taken for acute pelvic pain during sports, and found that the prevalence of avulsion fractures in the pelvis in youth soccer is $17.7 \%$ ( 74 of 418 radiographs). The ischial tuberosity was the most common avulsion site (table 6).

\section{Catastrophic Injuries}

Fortunately, catastrophic injuries in soccer are rare. A summary of catastrophic injuries in youth soccer is shown in table 7 [58-60]. Death in youth soccer is usually related to falling goalposts. Goalposts rarely fall during the course of normal play, and most accidents related to goalposts are due to climbing or hanging from the goalposts [58,59]. Goalposts should be properly secured, and the playing field should be cleared of all debris to create a safe environment [60, 61]. In 2003, Filipe et al. [62] outlined the severity and long-term sequelae of 168 eye injuries in soccer. Forty-eight of the 168 injuries occurred among 
Table 6. Injury types in youth soccer. All studies prospective unless indicated

\begin{tabular}{|c|c|c|c|c|c|c|c|c|c|c|c|}
\hline Study & $\begin{array}{l}\text { Total } \\
\text { number of } \\
\text { injuries }\end{array}$ & Abrasion & Contusion & Concussion & Laceration & $\begin{array}{l}\text { Fracture/ } \\
\text { Dislocation }\end{array}$ & Pain (site) & Sprain & Strain & $\begin{array}{l}\text { Tendonitis/ } \\
\text { Inflammation }\end{array}$ & Other \\
\hline $\begin{array}{l}\text { Nilsson } \\
{[15]}\end{array}$ & 1,534 & $336,39 \%$ & $306,36 \%$ & & & $29,3.5 \%$ & & $\begin{array}{l}174,20 \% \\
\text { (strains and } \\
\text { sprains) }\end{array}$ & & & $\begin{array}{l}13, \\
1.5 \%\end{array}$ \\
\hline $\begin{array}{l}\text { Sullivan } \\
{[16]}\end{array}$ & 34 & & $13,38.2 \%$ & & & $3,8.8 \%$ & & $12,35.3 \%$ & $3,8.8 \%$ & & $\begin{array}{l}3, \\
8.8 \%\end{array}$ \\
\hline $\begin{array}{l}\text { McCarroll } \\
\text { [14] }\end{array}$ & 176 & & $44,25.0 \%$ & $5,2.8 \%$ & & $22,12.5 \%$ & & $47,26.7 \%$ & $17,9.7 \%$ & & $\begin{array}{l}41, \\
23.3 \%\end{array}$ \\
\hline Hoff [32]* & $\begin{array}{l}\mathrm{O}=46 \\
\mathrm{I}=74\end{array}$ & & $\begin{array}{l}\mathrm{O}=8 \\
\mathrm{I}=14\end{array}$ & & & $\begin{array}{l}\mathrm{O}=1 \\
\mathrm{I}=7\end{array}$ & & $\begin{array}{l}\mathrm{O}=16 \\
\mathrm{I}=30\end{array}$ & $\begin{array}{l}\mathrm{O}=11 \\
\mathrm{I}=17\end{array}$ & & $\begin{aligned} \mathrm{O} & =10 ; \\
\mathrm{I} & =6\end{aligned}$ \\
\hline $\begin{array}{l}\text { Maehlum } \\
{[19]}\end{array}$ & 411 & & $193,47.0 \%$ & & $74,18.0 \%$ & $27,6.6 \%$ & & $89,21.7 \%$ & & & $\begin{array}{l}28 \\
6.8 \%\end{array}$ \\
\hline $\begin{array}{l}\text { Backous } \\
{[13]}\end{array}$ & 216 & 4 & 69 & & & & & 35 & 61 & 10 & 37 \\
\hline $\begin{array}{l}\text { Schmidt- } \\
\text { Olsen [18] }\end{array}$ & 312 & & & $1.2 \%$ & & $4 \%$ & $\begin{array}{l}14 \% \\
\text { (back) }\end{array}$ & & & & \\
\hline Kibler [21] & 179 & & $32 \%$ & $1.5 \%$ & & $9 \%$ & & $21.8 \%$ & $24.5 \%$ & & $4.5 \%$ \\
\hline Jones $[56]^{* *}$ & 23 & & & & & $\begin{array}{l}\text { Blow-out } \\
\text { fracture }=7\end{array}$ & & & & & \\
\hline Inklaar [26] & 83 & & 12 & & & 2 & & 14 & 7 & & 8 \\
\hline Heidt [53] & 98 & & 15 & & & 7 & & 25 & 23 & 9 & \\
\hline $\begin{array}{l}\text { Elias } \\
{[23]^{* * * *}}\end{array}$ & 3,840 & & & $\begin{array}{l}71,0.24 \text { per } \\
1,000 \mathrm{~h}\end{array}$ & & $\begin{array}{l}164,0.56 \\
\text { per } 1,000 \mathrm{~h}\end{array}$ & & $\begin{array}{l}577,1.99 \\
\text { per } 1,000 \mathrm{~h} \\
\text { (ankle } \\
\text { sprain only) }\end{array}$ & & & \\
\hline $\begin{array}{l}\text { Soderman } \\
\text { Injury } \\
\text { specific } \\
\text { studies }\end{array}$ & 79 & & 8 & & & 4 & 19 & 25 & 15 & 3 & 5 \\
\hline
\end{tabular}




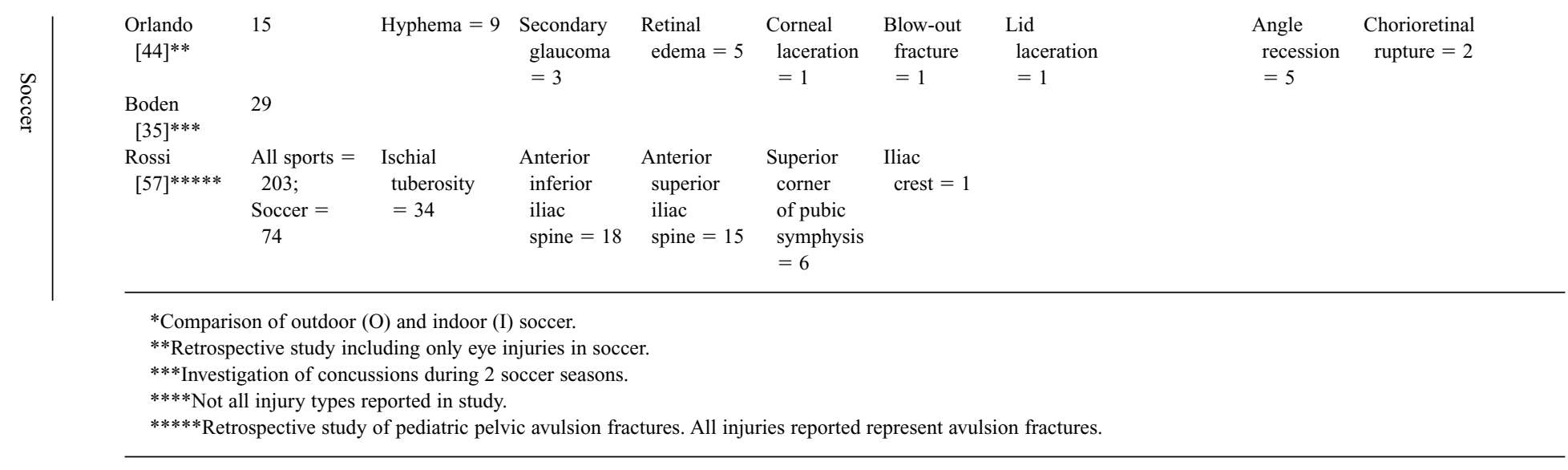


Table 7. Catastrophic injuries in youth soccer

\begin{tabular}{|c|c|c|c|c|c|c|c|c|c|c|}
\hline Study & $\begin{array}{l}\text { Total } \\
\text { number of } \\
\text { injuries }\end{array}$ & Mechanism & $\begin{array}{l}\text { Fatal } \\
\text { injuries }\end{array}$ & Contusion & Concussion & Laceration & Fracture & $\begin{array}{l}\text { Cardiac } \\
\text { injury }\end{array}$ & Other & Comment \\
\hline Blond [58] & 117 & $\begin{array}{l}\text { Falling } \\
\text { goalpost }\end{array}$ & 2 & 40 & 6 & 25 & 37 & & 9 & $\begin{array}{l}\text { Fatal and severe injury } \\
\text { were due to hanging } \\
\text { on the goalposts }\end{array}$ \\
\hline $\begin{array}{l}\text { DeMarco } \\
{[59]}\end{array}$ & 27 & $\begin{array}{l}\text { Falling } \\
\text { goalpost }\end{array}$ & 18 & & & & & & & $\begin{array}{l}\text { Goalposts should be } \\
\text { secured properly }\end{array}$ \\
\hline $\begin{array}{l}\text { Stephenson } \\
{[60]}\end{array}$ & 1 & $\begin{array}{l}\text { Cranium } \\
\text { impaled } \\
\text { on fence }\end{array}$ & 1 & & & & & & & $\begin{array}{l}\text { Fences and debris } \\
\text { should be positioned } \\
\text { away from } \\
\text { playing field }\end{array}$ \\
\hline
\end{tabular}


children: Thirty-five were severe (causing permanent visual deficit), and 13 were nonsevere.

\section{Time Loss}

A comparison of injury severity in youth soccer is shown in table $8[10,16$, $21,22,28]$. The definition of injury and the grading of injury severity varies in the available studies on pediatric soccer injuries. The most widely accepted definition is from Engström et al. [63]. However, the FIFA-MARC has recently modified the definition to include chronic injuries $[5,30]$ as follows:

(1) Minor Acute: Absence from participation more than one day, but less than one week.

(2) Moderate Acute: Absence from participation of more than 1 week, but less than 4 weeks.

(3) Severe Acute: Absence from participation of more than 4 weeks.

(4) Minor Chronic: Complaint of pain for more than 2 weeks, but less than 4 weeks that does not prevent participation.

(5) Moderate Chronic: Complaint of pain for more than 4 weeks that does not prevent participation.

(6) Severe Chronic (e.g. stress fractures).

Review of the data in table 8 shows that approximately $70-80 \%$ of the injuries in youth soccer are minor or moderate, and do not result in a significant loss of time from play. Of 113 severe injuries (both pediatric and adult) that resulted in greater than 4 weeks absence from play, $22.7 \%$ occurred in players less than 16 years old, and $25.3 \%$ occurred in players aged 16-18 years. Also, the incidence of severe injuries was twice as high in low skilled players compared to highly skilled players [64].

\section{Injury Outcome}

An awareness of the propensity for knee injuries in female soccer players is particularly important for the sports medicine professional, as 12 years postinjury, $34 \%$ of previous female soccer players in Sweden who suffered an ACL injury have radiographic changes consistent with osteoarthritis [65]. Although there have been no longitudinal studies on the long-term outcome of pediatric soccer injuries, the incidence of hip and knee arthritis for former adult soccer players is much higher when compared to age-matched controls $[66,67]$.

The relationship of chronic traumatic brain injury and soccer remains a controversial topic, as soccer players exhibit deficiencies in memory and planning compared to controls $[68,69]$. In contrast, a recent study used similar neuropsychological tests to those used by Matser et al. [69], and showed that soccer-related concussions were not associated with impaired neurocognitive function [70]. A laboratory study in which a size four ball was lobbed from 
Table 8. A comparison of injury severity in youth soccer. All studies are prospective unless indicated

\begin{tabular}{|c|c|c|c|c|c|}
\hline Study & Year & $\begin{array}{l}\text { Sample number } \\
\text { (number of players } \\
\text { unless indicated) }\end{array}$ & Minor injury & Moderate injury & Severe or major injury \\
\hline Sullivan & 1980 & 1,272 & & 7 & 1 \\
\hline Kibler* & 1993 & $\begin{array}{l}74,900 \text { player } \\
\text { hours }\end{array}$ & $\begin{array}{l}1 \text { st degree }=38 \% ; \\
1 \text { st degree }+=24.5 \%\end{array}$ & $\begin{array}{l}\text { 2nd degree }=21.8 \% \\
2 \text { nd degree }+=7 \%\end{array}$ & $\begin{array}{l}\text { 3rd degree }=8 \% \\
3 \text { rd degree }+=0.6 \%\end{array}$ \\
\hline Junge** & 2000 & $\begin{array}{l}\text { France }=131 \\
\text { Czech }=180\end{array}$ & $\begin{array}{l}\text { France }=40.4 \% \\
\text { Czech }=40.0 \%\end{array}$ & $\begin{array}{l}\text { France }=31.6 \% \\
\text { Czech }=35.45 \%\end{array}$ & $\begin{array}{l}\text { France }=28.1 \% \\
\text { Czech }=24.6 \%\end{array}$ \\
\hline Soderman** & 2001 & 175 & 26 & 41 & 11 \\
\hline Junge** & 2002 & $\begin{array}{l}\text { Trained }=101 \\
\text { Control }=93\end{array}$ & $\begin{aligned} \text { Trained } & =0.46 ; \\
\text { Control } & =0.80^{¥}\end{aligned}$ & $\begin{array}{l}\text { Trained }=0.17 \\
\text { Control }=0.24\end{array}$ & $\begin{array}{l}\text { Trained }=0.14 \\
\text { Control }=0.16\end{array}$ \\
\hline
\end{tabular}

$*$ Moderate $=>7$ days missed, Severe $=$ season out.

$* *$ No clarification of 1 st -3 rd degree rating system provided by author.

$* * *$ Mild $\geq 1$ week loss of participation, Moderate $=2-3$ weeks loss of participation, Severe $=>4$ weeks loss of participation; $\mathrm{N}=$ percentage of injuries.

$* * * *$ Minor $=0-7$ days absent, Moderate $=7-30$ days absent, Major $=>30$ days absent; $\mathrm{N}=$ number of injuries.

${ }^{\text {¥}}$ Statistically significant value $(\mathrm{p}<0.05)$. 
three meters found that the greatest peak accelerometer readings had a head injury criteria of only 61 , where 1,000 is threshold for brain injury [71]. Naunheim et al. [72] measured head impacts by a triaxial accelerometer placed in a helmet and showed that significantly higher values were reached in soccer than in hockey or football. However, all soccer values were much lower than the impact values needed to cause acute brain injury.

Janda et al. [73] tested the use of padded goalposts in 471 games: no injuries resulted from 7 player/padded post collisions during a 3-year study [73]. They also tested the padded goal posts in the laboratory and showed that the modified posts, even after 2 years of outside exposure, significantly decreased object to post impact force.

\section{Injury Risk Factors}

\section{Dangerous Play}

Injuries resulting from fouls are potentially preventable injuries. The punishments of a free kick and a yellow or red card for foul tackles are risk control measures that are intended to modify players' behaviors to minimize the number of unsafe acts that expose players to high risk situations. In a study of 4 FIFA tournaments, $63 \%$ of tackles that resulted in foot and ankle injuries were deemed to be the result of foul play [51]. Moreover, FIFA [74] specifically declared before the 1998 World Cup competition in France that referees should treat tackles from behind as a foul. Despite this ruling, the proportion of injuries caused by tackles from behind was still high (24\%) in the four competitions assessed by Giza et al. [51]. Therefore, youth soccer matches should have adequate refereeing and adhere to the FIFA 'Fair Play' principles [74].

Most concussions are related to collision with another player or the post. Concussions are more likely to occur with rough play, on small fields, and in the penalty area [75].

Age

Soderman [76] found that $59 \%$ of females below the age of 16 years playing on senior teams (teams with an average age over 20 years) sustained ACL injuries during contact situations. The authors suggested that female soccer players under the age of 16 years should not be allowed to participate in games at a senior level [76].

\section{Gender}

The three to four times higher rate of ACL tear in females compared to males has been attributed to many factors, including joint laxity, core stability, 
hormonal influence, femoral notch size, and hamstring weakness [9, 77-79]. A recent study in a sheep model by Strickland et al. [80] demonstrated that estrogen did not have an effect on failure of the ACL. However, others have shown an increase in ACL injuries during the ovulatory phase of menstruation [79]. The gender discrepancy in ACL tears appears to be a combination of dynamic factors [78], and there is a low correlation between isokinetic strength measurements and functional tests in adult female soccer players [81].

Level of Play

Elite and professional players achieve a higher level of fitness than recreational players [82], and this fitness level may be protective. Junge et al. [47] have shown a lower injury rate in elite players compared to less skilled players, and a prospective cohort study from the FIFA-MARC showed that the incidence of soccer injuries can be reduced by preventative interventions, especially in low-skill level youth teams [28]. A review of injuries in the elite Women's United Soccer Association by Giza et al. [7] found a relatively low ACL injury rate of 0.09 per 1,000 hours which could represent a 'pre-selection' phenomenon in which players who are at risk for an ACL injury may have had an injury earlier in their career and not reached the Women's United Soccer Association or have had a reconstruction prior to their participation in the Women's United Soccer Association.

\section{Physical Maturity}

In 1988, Backous et al. [13] found that boys with the highest incidence of injury were tall (greater than $165 \mathrm{~cm}$ ) and had a weak grip (less than $25 \mathrm{~kg}$ ), suggesting that skeletally mature but muscularly weak boys may be more susceptible to injury while playing soccer with peers of the same chronological age.

\section{Suggestions for Injury Prevention}

The studies that have addressed injury prevention are summarized in table $9[28,53,71-73,81,83,84]$. Review of this table suggests the following preventive measures which are discussed below: shin guards, preseason conditioning, and recognition of physical capabilities.

\section{Shin Guards}

While other sports include the use of protective equipment, the main source of protection in soccer is shin guards. Shin guards most likely reduce the incidence of soft tissue injuries, but clinical evidence is lacking. Boden et al. [85] investigated thirty-one fractures of the tibia and fibula in soccer, and found that 
Table 9. Suggestions for injury prevention and improved fitness in youth soccer

\begin{tabular}{|c|c|c|c|c|c|}
\hline Study & Year & Design & Purpose & Findings & Conclusions \\
\hline Junge [28] & 2002 & $\begin{array}{l}\text { Prospective, } \\
\text { cohort }\end{array}$ & $\begin{array}{l}\text { Evaluate the effects of a } \\
\text { prevention program on } \\
\text { the incidence of soccer } \\
\text { injuries in male youth } \\
\text { amateur players }\end{array}$ & $\begin{array}{l}\text { The prevention group } \\
\text { had significantly less players } \\
\text { injured (Prevention }=53, \\
\text { Control }=67, \mathrm{p}<0.001) \\
\text { For low skilled players, the } \\
\text { prevention group had significantly } \\
\text { less injuries per } 1,000 \text { player } \\
\text { hours (Prevention }=6.95, \\
\text { Control }=11.1, \mathrm{p}<0.05 \text { ) }\end{array}$ & $\begin{array}{l}\text { The incidence of soccer } \\
\text { injuries can be reduced by } \\
\text { preventative interventions, } \\
\text { especially in low-skill } \\
\text { level youth teams }\end{array}$ \\
\hline Heidt [53] & 2000 & $\begin{array}{l}\text { Prospective, } \\
\text { cohort }\end{array}$ & $\begin{array}{l}\text { Evaluate the role that } \\
\text { preseason conditioning } \\
\text { had on the occurrence } \\
\text { and severity of injury in } \\
\text { female soccer players }\end{array}$ & $\begin{array}{l}\text { Less injuries in the preseason } \\
\text { training group (Training }=14 \% \text {, } \\
6 \text { injuries in } 42 \text { players; } \\
\text { Control }=33.7 \%, 87 \text { injuries } \\
\text { in } 258 \text { players) }\end{array}$ & $\begin{array}{l}\text { Preseason conditioning } \\
\text { resulted in an overall } \\
\text { reduction of injuries to } \\
\text { adolescent women playing } \\
\text { competitive soccer }\end{array}$ \\
\hline Hewett [83] & 1999 & $\begin{array}{l}\text { Prospective, } \\
\text { multiple } \\
\text { sports }\end{array}$ & $\begin{array}{l}\text { To test the effect of } \\
\text { neuromuscular training } \\
\text { on the incidence of } \\
\text { knee injury in female } \\
\text { athletes }\end{array}$ & $\begin{array}{l}97 \text { trained females, } 193 \text { untrained } \\
\text { females, and } 209 \text { male control } \\
\text { soccer players were compared } \\
6 \text { severe knee injuries occurred in } 5 \\
\text { untrained females and } 1 \text { male } \\
\text { control } \\
\text { No injuries occurred } \\
\text { in the trained female group }\end{array}$ & $\begin{array}{l}\text { Decreased incidence of } \\
\text { knee injury in female } \\
\text { soccer players compared } \\
\text { to untrained females } \\
\text { utilizing a group of male } \\
\text { controls. Subset reported } \\
\text { of soccer, but study } \\
\text { included basketball and } \\
\text { volleyball also }\end{array}$ \\
\hline
\end{tabular}


Table 9 (continued)

\begin{tabular}{|c|c|c|c|c|c|}
\hline Study & Year & Design & Purpose & Findings & Conclusions \\
\hline Janda [73] & 1995 & $\begin{array}{l}\text { Part I: } \\
\text { Prospective } \\
\text { Part II: } \\
\text { Laboratory } \\
\text { testing of } \\
\text { goalposts }\end{array}$ & $\begin{array}{l}\text { Present laboratory and } \\
\text { clinical experience } \\
\text { with padded goal posts } \\
\text { for preventing head } \\
\text { injury in soccer }\end{array}$ & $\begin{array}{l}\text { Padded goal posts significantly } \\
\text { decrease object to post impact } \\
\text { force in laboratory testing. } \\
\text { No injuries resulted from } 7 \\
\text { player/padded post collisions } \\
\text { during a 3-year study }\end{array}$ & $\begin{array}{l}\text { Subjective questioning of } \\
\text { players and coaches } \\
\text { revealed did not feel that } \\
\text { padded posts negatively } \\
\text { effected game play or } \\
\text { outcome }\end{array}$ \\
\hline $\begin{array}{l}\text { Naunheim } \\
{[72]}\end{array}$ & 2000 & $\begin{array}{l}\text { Prospective } \\
\text { measurements } \\
\text { of force in } \\
\text { hockey and } \\
\text { football, } \\
\text { laboratory } \\
\text { testing of } \\
\text { heading } \\
\text { in soccer }\end{array}$ & $\begin{array}{l}\text { To compare acceleration } \\
\text { forces to the head } \\
\text { in high school-level } \\
\text { football, hockey and } \\
\text { soccer players }\end{array}$ & $\begin{array}{l}\text { Hockey and football scores from } \\
\text { impact during game, but } \\
\text { soccer from ball from } 30 \text { yards } \\
\text { traveling } 39 \mathrm{mph} \\
\text { Peak g's: Football }=29 \text {, } \\
\text { Hockey }=35 \text {, } \\
\text { Soccer }=55\end{array}$ & $\begin{array}{l}\text { Impacts measured by a } \\
\text { triaxial accelerometer } \\
\text { placed in a helmet were } \\
\text { significantly higher } \\
\text { in soccer than in hockey } \\
\text { or football; however, all } \\
\text { soccer values were much } \\
\text { lower than the impact of } \\
200 \mathrm{~g} \text { needed to cause } \\
\text { acute brain injury }\end{array}$ \\
\hline Reed [71] & 2002 & $\begin{array}{l}\text { Part I : Eye } \\
\text { exam regular } \\
\text { play } \\
\text { Part II: Field } \\
\text { testing of } \\
\text { soccer ball } \\
\text { to head } \\
\text { impact with } \\
\text { accelerometer }\end{array}$ & $\begin{array}{l}\text { Define forces of youth } \\
\text { soccer heading and } \\
\text { determine if it is linked } \\
\text { to retinal hemorrhage }\end{array}$ & $\begin{array}{l}\text { After } 2 \text { weeks of regular play with } \\
\text { an average of } 79 \text { headers, eye } \\
\text { exams in } 21 \text { soccer players } \\
\text { were no different than } 30 \text { controls } \\
\text { With ball lobbed from } 3 \text { meters, } \\
\text { the mean peak cranial } \\
\text { acceleration was } 3.7 \pm 1.3 \\
\text { Even for greatest impact } \\
\text { observed, head injury } \\
\text { criteria }=61 \text {, where } 1,000 \text { is } \\
\text { threshold for brain injury }\end{array}$ & $\begin{array}{l}\text { Routine headers not } \\
\text { associated with globe } \\
\text { impact are unlikely to } \\
\text { cause retinal } \\
\text { hemorrhage }\end{array}$ \\
\hline
\end{tabular}




$\begin{array}{cc}\text { Diallo [84] } \quad 2001 \quad \begin{array}{l}\text { Laboratory } \\ \text { testing on } \\ \text { group of } \\ \end{array} \\ & \text { soccer players } \\ & \text { and controls }\end{array}$

Ostenberg

1998
To determine the effects of short-term plyometric training and detraining on motor performance in pubescent soccer players

Compare isokinetic knee muscle strength, functional performance, aerobic capacity, and general joint laxity between female soccer players $>20$ years old and $<20$ years old
10 weeks of specific plyometric training revealed a significant increase in jump, running, and sprint-cycling

performances vs. controls

Results remained after 8 weeks of detraining

Younger players had significantly lower values of isokinetic knee flexor strength, older players had a significantly higher BMI No significant differences for functional performance tests, aerobic capacity, or general joint laxity 
$90 \%$ of players were wearing shin guards at the time of injury, and commented that shin guards are not likely to be helpful after a certain critical force is exceeded. Boden also reviewed the biomechanical studies that have been performed on shin guards and summarized that shin guards decrease the magnitude of forces on the tibia by prolonging the contact time. Depending on the type of shin guard, the load forces were reduced by $41.2-77.1 \%$ [31].

\section{Preseason Conditioning}

Some authors have shown that preseason neuromuscular training and plyometrics can decrease knee injury rates in females [53, 83, 86]. Heidt et al. [53] evaluated the role that preseason conditioning had on the occurrence and severity of injury in 300 female high school soccer players. The conditioning group of 42 players suffered 6 injuries (one ACL tear), while the control group of 258 players suffered 87 injuries (8 ACL tears) [53]. Hewett et al. [83] performed a prospective cohort study in high school soccer, basketball, and volley ball players in which knee injuries were compared between a preseason conditioned group, a nonconditioned group, and male controls. They found that six severe knee injuries occurred in 5 untrained females and one male control, and that no injuries occurred in the trained female group. Both studies show the positive trends of preventative training, but studies with a large, national injury registry will be needed to statistically prove their effect. In a 3-year prospective study using proprioceptive training for semi-professional soccer players, Caraffa et al. [87] found a significantly lower rate of ACL injury in the trained team compared to the untrained controls [88].

The advent of competitive soccer in the United States has resulted in the opportunity for youngsters to play soccer year round. While increased play can lead to improved skill levels, balance of training is important. Diallo et al. [84] compared a group of 12-year-old boys who underwent a strengthening and fitness program to a control group who only played soccer. They showed that 10 weeks of specific plyometric training resulted in a significant increase in jump, running, and sprint-cycling performances versus controls. They also found that the results remained even after 8 weeks of detraining [84].

\section{Physical Capabilities}

The maturation process can also effect the level of play that a soccer athlete achieves. Malina et al. [89] performed a laboratory study on groups of 12-year-old soccer players where height, body mass index, chronological and skeletal age were compared to physical capabilities. They found that elite soccer systematically excludes late maturing boys and favors average and early maturing boys. Reilly et al. [82] have shown that there are anthropometric and physiological predispositions for elite soccer. They state that players may not 
need to have an extraordinary capacity within any areas of physical performance criteria, but must possess a reasonably high level within all areas, such as muscle strength, aerobic capacity, speed, and coordination. Player position is also related to his or her physiological capacity. Thus, mid-field players and defenders have the highest maximal oxygen intakes and perform best on intermittent exercise tests.

\section{Suggestions for Future Research}

Kirkendall and associates at the United States Soccer Federation have commented that, to further our understanding of the relationship between heading, head injury and cognitive deficits, we need to: learn more about the actual impact of a ball on the head, verify the exposure to heading at all ages and competitive levels, determine stable estimates of concussive injury rates across the soccer spectrum, conduct prospective longitudinal studies on soccer players focusing on exposure, injury and cognition, and determine the minimum safe age to begin instruction on the skill of heading [75]. Until the above suggestions can be accomplished, it is important for coaches to teach young soccer players correct heading techniques, such as centering the ball on the forehead, correct timing, and strengthening of the neck muscles. It is also important that parents and coaches are aware of the type of ball used. The balls should be made of a light-weight material that does not readily absorb water during rainy or wet conditions. All young children should use size three balls, and older children should use size four balls. The use of standard size five balls should be reserved for adults and adult-sized teenagers.

Future research should be directed towards longitudinal outcome studies of pediatric soccer injuries to identify those injuries which preclude continuation of the game into adulthood. To accomplish this difficult epidemiological task, injury data surveillance systems will be needed. Currently, comprehensive databases which track injury diagnosis, treatment and outcomes are in place in the National Collegiate Athletic Association and Major League Soccer. Inclusion of these databases by the United States Soccer Federation youth programs is the best model to follow players throughout an established soccer system.

\section{References}

1 Metzl JD: Sports-specific concerns in the young athlete: Soccer. Pediatr Emerg Care 1999; 15:130-134.

2 Metzl JD, Micheli LJ: Youth soccer: An epidemiologic perspective. Clin Sports Med 1998; 17:663-673.

3 Soccer Industry Council of America: North Palm Beach, FL 33048: Soccer Industry Council of America; 1999. 
4 Jones SJ, Lyons RA, Sibert J, Evans R, Palmer SR: Changes in sports injuries to children between 1983 and 1998: Comparison of case series. J Public Health Med 2001;23:268-271.

5 Dvorak J, Junge A: Football Injuries and Physical Symptoms. Am J Sports Med 2000;28:S3-S9.

6 Hawkins R, Fuller C: A prospective epidemiological study of injuries in four English professional football clubs. Br J Sports Med 1999;33:196-203.

7 Giza E, Mithoefer K, Farrell L, Zarins B, Gill T: Injuries in Women's Professional Soccer. Br J Sports Med 2004. In Print.

8 Engstrom B, Johansson C, Tornkvist H: Soccer injuries among elite female players. Am J Sports Med 1991;19:372-375.

9 Ostenberg A, Roos H: Injury risk factors in female European football. A prospective study of 123 players during one season. Scand J Med Sci Sports 2000;10:279-285.

10 Soderman K, Adolphson J, Lorentzon R, Alfredson H: Injuries in adolescent female players in European football: A prospective study over one outdoor soccer season. Scand J Med Sci Sports 2001;11:299-304.

11 Inklaar H: Soccer injuries I: Incidence and severity. Sports Med 1994;18:55-73.

12 Drawer S, Fuller C: An economic framework for assessing the impact of injuries in professional football. Safety Science 2001;39:in press.

13 Backous DD, Friedl KE, Smith NJ, Parr TJ, Carpine WD Jr: Soccer injuries and their relation to physical maturity. Am J Dis Child 1988;142:839-842.

14 McCarroll J, Meaney C, Sieber J: Profile of Youth Soccer Injuries. Phys Sportsmed 1984; 12:113-117.

15 Nilsson S, Roaas A: Soccer injuries in adolescents. Am J Sports Med 1978;6:358-361.

16 Sullivan J, Gross R, Grana W, Garcia-Moral C: Evaluation of injuries in youth soccer. Am J Sports Med 1980;8:325-327.

17 Schmidt-Olsen S, Bunemann LK, Lade V, Brassoe JO: Soccer injuries of youth. Br J Sports Med 1985;19:161-164.

18 Schmidt-Olsen S, Jorgensen U, Kaalund S, Sorensen J: Injuries among young soccer players. Am J Sports Med 1991;19:273-275.

19 Maehlum S, Dahl E, Daljord O: Frequency of injuries in a youth soccer tournament. Phys Sportsmed 1986;14:73-79.

20 Maehlum S, Daljord O, Hansen KJ: Frequency of injuries in youth soccer. Med Sci Sports 1999;31:S401.

21 Kibler W: Injuries in adolescent and preadolescent soccer players. Med Sci Sports Exerc 1993; 25:1330-1332.

22 Junge A, Chomiak J, Dvorak J: Incidence of football injuries in youth players. Am J Sports Med 2000;28:S47-S57.

23 Elias SR: 10-year trend in USA Cup soccer injuries: 1988-1997. Med Sci Sports Exerc 2001; 33:359-367.

24 Maehlum S, Daljord OA: Football injuries in Oslo: A one-year study. Br J Sports Med 1984; 18:186-190.

25 Nielsen A, Yde J: Epidemiology and traumatology of injuries in soccer. Am J Sports Med 1989; 17:803-807.

26 Inklaar H, Bol E, Schmikli S: Injuries in Male Soccer players: Team risk analysis. Int J Sports Med 1996;17:229-234.

27 Peterson L, Junge A, Chomiak J, Graf-Baumann T, Dvorak J: Incidence of football injuries and complaints in different age groups and skill-level groups. Am J Sports Med 2000;28:S51-S57.

28 Junge A, Rosch D, Peterson L, Graf-Baumann T, Dvorak J: Prevention of soccer injuries: A prospective intervention study in youth amateur players. Am J Sports Med 2002;30:652-659.

29 Powell JW, Barber-Foss KD: Traumatic brain injury in high school athletes (comment). JAMA 1999;282:958-963.

30 Junge A, Chomiak J, Peterson L, Graf-Baumann T, Dvorak J: Goalkeepers - Physical performance, psychological characteristics and incidence of injuries. Personal Communication 2001.

31 Boden B: Leg injuries and shin guards. Clin Sports Med 1998;17:769-777.

32 Hoff G, Martin T: Outdoor and indoor soccer: Injuries among youth players. Am J Sports Med 1986;14:231-233. 
33 Hawkins R, Hulse M, Wilkinson C, Hodson A, Gibson M: The association football medical research programme: An audit of injuries in professional football. Br J Sports Med 2001;35: 43-47.

34 Inklaar H: Soccer injuries II: Aetiology and prevention. Sports Med 1994;18:81-93.

35 Boden B, Kirkendall D, Garrett W: Concussion incidence in elite college soccer players. Am J Sports Med 1998;26:238-241.

36 Dvorak J, Peterson L, Junge A: Risk factors and incidence of injury in football players. Am J Sports Med 2000;28:1-74.

37 Hawkins R, Fuller C: An examination of the frequency and severity of injuries and incidents at three levels of professional football. Br J Sports Med 1998;32:326-332.

38 Ekstrand J, Gillquist J: Soccer injuries and their mechanisms: A prospective study. Med Sci Sports 1983;15:267-270.

39 Bjordal JM, Arnly F, Hannestad B, Strand T: Epidemiology of anterior cruciate ligament injuries in soccer. Am J Sports Med 1997;25:341-345.

40 Micheli LJ, Metzl JD, Di Canzio J, Zurakowski D: Anterior cruciate ligament reconstructive surgery in adolescent soccer and basketball players. Clin J Sport Med 1999;9:138-141.

41 Arendt E, Dick R: Knee injury patterns among men and women in collegiate basketball and soccer NCAA data and review of literature. Am J Sports Med 1995;23:694-701.

42 NCAA. Injury Surveillance System, Men's Soccer. Indianapolis: National Collegiate Athletic Association; 2000.

43 NCAA. Injury Surveillance System, Women's Soccer. Indianapolis: National Collegiate Athletic Association; 2000.

44 Orlando R: Soccer-related eye injuries in children and adolescents. Phys Sportsmed 1988;16: 103-106.

45 Boyd KT, Brownson P, Hunter JB: Distal radial fractures in young goalkeepers: A case for an appropriately sized soccer ball. Br J Sports Med 2001;35:409-411.

46 Junge A: The influence of psychological factors on sports injuries. Am J Sports Med 2000;28: S10-S15.

47 Junge A, Dvorak J, Chomiak J, Peterson L, Graf-Baumann T: Medical history and physical findings in football players of different ages and skill levels. Am J Sports Med 2000;28:S16-S21.

48 Lindenfeld T, Schmitt D, Hendy M, Mangine R, Noyes F: Incidence of injury in indoor soccer. Am J Sports Med 1994;22:364-371.

49 Putukian M, Knowles W, Swere S, Castle N: Injuries in indoor soccer. Am J Sports Med 1996;24:317-322.

50 Dvorak J, Junge A, Chomiak J, Graf-Baumann T, Peterson L, Rosch D, Hodgson R: Risk factor analysis for injuries in football players. Am J Sports Med 2000;28:S69-S74.

51 Giza E, Fuller C, Junge A, Dvorak J: Mechanisms of foot and ankle injuries in soccer. Am J Sports Med 2003;31:550-554.

52 Delfico A, Garrett W: Mechanisms of injury of the ACL in soccer players. Clin Sports Med 1998;17:779-785.

53 Heidt RS Jr, Sweeterman LM, Carlonas RL, Traub JA, Tekulve FX: Avoidance of soccer injuries with preseason conditioning. Am J Sports Med 2000;28:659-662.

54 Casa D, Armstrong L, Hillman S, Montain S, Reiff R, RIch B, Roberts W, Stone J: National Athletic Trainers' Association Position Statement: Fluid replacement for athletes. J Athl Train 2002;35:212-224.

55 Binkley H, Beckett J, Casa D, Kleiner D, Plummer P: National Athletic Trainers' Association Position Statement: Exertional heat illness. J Athl Train 2002;37:329-343.

56 Jones N: Orbital blowout fractures in sport. Br J Sports Med 1994;28:272-275.

57 Rossi F, Dragoni S: Acute avulsion fractures of the pelvis in adolescent competitive athletes: Prevalence, location, and sports distribution of 203 cases collected. Skeletal Radiol 2001;30: 127-131.

58 Blond L, Hansen L: Injuries caused by falling soccer goalposts in Denmark. Br J Sports Med 1999;33:110-112.

59 DeMarco J, Reeves C: Injuries associated with soccer goalposts - United States, 1979-1993. MMWR 1994;43:153-155. 
60 Stephenson G, Gibson R: Fatal penetrating head injury during a game of soccer. Injury 1992;23:197-198.

61 Fuller C, Hawkins R: Assessment of football grounds for player safety. Safety Science 1997;2: 115-128.

62 Filipe JC, Fernandes V, Barros H, Falcao-Reis F, Castro-Correia J: Soccer-related ocular injuries. Arch Ophthalmol 2003;121:687-694.

63 Engstrom B, Forssblad M, Johansson C, Tornkvist H: Does a major knee injury definitely sideline an elite soccer player? Am J Sports Med 1990;18:101-105.

64 Chomiak J, Junge A, Peterson L, Dvorak J: Severe injuries in football players. Am J Sports Med 2000;28:S58-S68.

65 Roos H, Ostenberg A, Lohmander L: High prevalence of knee OA and functional limitations in female soccer players with ACL injury. Conference Proceedings: Presentation on female soccer injuries; Gothenburg, Sweden; October 2001.

66 Larsen E, Jensen P, Jensen P: Long term outcome of knee and ankle injuries in elite football. Scand J Med Sci Sports 1999;9:285-289.

67 Lindberg H, Roos H, Gardsell P: Prevalence of coxarthosis in former soccer players. Acta Orthop Scand 1993;64:165-167.

68 Tysvaer AT: Head and neck injuries in soccer. Impact of minor trauma. Sports Med 1992;14: 200-213.

69 Matser E, Kessels A, Lezak M, Jordan B, Troost J: Neuropsychological impairment in amateur soccer players. JAMA 1999;282:971-973.

70 Guskiewicz KM, Marshall SW, Broglio SP, Cantu RC, Kirkendall DT: No evidence of impaired neurocognitive performance in collegiate soccer players. Am J Sports Med 2002;30: $157-162$.

71 Reed W, Feldman K, Weiss A, Tencer A: Does soccer ball heading cause retinal bleeding? Arch Pediatr Adolesc Med 2002;156:337-340.

72 Naunheim R, Standeven J, Richter C, Lewis L: Comparison of impact data in hockey, football, and soccer. J Trauma 2000;48:938-941.

73 Janda D, Bir C, Wild B, Olson S, Hensinger R: Goal Post injuries in soccer. Am J Sports Med 1995;23:340-344.

74 FIFA. FIFA Handbook, Laws of the Game. Zurich: FIFA; 1998.

75 Kirkendall DT, Jordan SE, Garrett WE: Heading and head injuries in soccer. Sports Med 2001; 31:369-386.

76 Soderman K, Pietila T, Alfredson H, Werner S: Anterior cruciate ligament injuries in young females playing soccer at senior levels. Scand J Med Sci Sports 2002;12:65-68.

77 Soderman K, Alfredson H, Pietila T, Werner S: Risk factors for leg injuries in female soccer players: A prospective investigation during one out-door season (comment). Knee Surg Sports Traumatol Arthros 2001;9:313-321.

78 Ireland ML: The female ACL: Why is it more prone to injury? Orthop Clin North Am 2002;33: 637-651.

79 Wojtys EM, Huston LJ, Boynton MD, Spindler KP, Lindenfeld TN: The effect of the menstrual cycle on anterior cruciate ligament injuries in women as determined by hormone levels. Am J Sports Med 2002;30:182-188.

80 Strickland S, Belknap T, Turner S, Wright T, Hannafin J: Lack of hormonal influences on mechanical properties of sheep knee ligaments. Am J Sports Med 2003;31:210-215.

81 Ostenberg A, Roos E, Ekdahl C, Roos H: Isokinetic knee extensor strength and functional performance in healthy female soccer players. Scand J Med Sci Sports 1998;8:257-264.

82 Reilly T, Bangsbo J, Franks A: Anthropometric and physiological predispositions for elite soccer. J Sports Sci 2000;18:669-683.

83 Hewett TE, Lindenfeld TN, Riccobene JV, Noyes FR: The effect of neuromuscular training on the incidence of knee injury in female athletes. A prospective study (comment). Am J Sports Med 1999;27:699-706.

84 Diallo O, Dore E, Duche P, Praagh EV: Effects of plyometric training followed by a reduced training programme on physical performance in prepubescent soccer players. J Sports Med Phys Fitness 2001;41:342-348. 
85 Boden BP, Lohnes JH, Nunley JA, Garrett WE Jr: Tibia and fibula fractures in soccer players. Knee Surg Sports Traumatol Arthrosc 1999;7:262-266.

86 Silvers HJ, Mandelbaum BR: Preseason conditioning to prevent soccer injuries in young women. Clin J Sport Med 2001;11:206.

87 Caraffa A, Cerulli G, Projetti M, Aisa G, Rizzo A: Prevention of anterior cruciate ligament injuries in soccer. A prospective controlled study of proprioceptive training. Knee Surg Sports Traumatol Arthrosc 1996;4:19-21.

88 Cerulli G, Benoit DL, Caraffa A, Ponteggia F: Proprioceptive training and prevention of anterior cruciate ligament injuries in soccer. J Orthop Sports Phys Ther 2001;31:655-660; discussion 61.

89 Malina R, Reyes MP, Eisenmann J, Horta L, Rodrigues J, Miller R: Height, mass and skeletal maturity of elite Portuguese soccer players aged 11-16 years. J Sports Sci 2000;18:685-693.

Dr. Lyle J. Micheli

319 Longwood Avenue

Boston, MA 02115 (USA)

Tel. +1 508355 6247, E-Mail mdjenkins@adelphia.net 